\title{
Detection of microcystin synthetase genes in health food supplements containing the freshwater cyanobacterium Aphanizomenon flos-aquae
}

\author{
M.L. Saker ${ }^{\mathrm{a}, *}$, A.-D. Jungblut ${ }^{\mathrm{b}}$, B.A. Neilan ${ }^{\mathrm{b}}$, D.F.K. Rawn ${ }^{\mathrm{c}}$, V.M. Vasconcelos ${ }^{\mathrm{a}, \mathrm{d}}$ \\ ${ }^{a}$ Department of Ecotoxicology, Centro Interdisciplinar de Investigação Marinha e Ambiental, Rua dos Bragas 289, 4050 Porto, Portugal \\ ${ }^{\mathrm{b}}$ School of Biotechnology and Biomolecular Sciences, University of New South Wales, Sydney, NSW 2052, Australia \\ ${ }^{\mathrm{c}}$ Food Research Division, Health Products and Food Branch, Health Canada, Sir Frederick Banting Building, \\ Tunneys Pasture (2203D), Ottawa, Ont., Canada K1A OL2 \\ ${ }^{\mathrm{d}}$ Departamento de Zoologia e Antropologia, Faculdade de Ciências, Universidade do Porto, Praça Gomes Teixeira, 4050 Porto, Portugal
}

\begin{abstract}
In this study we investigated the presence of toxin-producing cyanobacterial contaminants in food supplements manufactured from blooms of the non-toxic freshwater cyanobacterium Aphanizomenon flos-aquae. Previous reports investigating the contamination of health food supplements with toxin-producing cyanobacteria have used chemical and or biochemical methods such as HPLC, ELISA and protein phosphatase assays. Whilst these studies have drawn attention to the presence of hepatotoxic microcystins in some commercially available food supplements, the methods used do not provide any information on the source of the contaminant. Such information would be useful for the quality control of food supplements produced for human consumption. In this study we applied a molecular technique, involving the amplification of the 16s rRNA gene, the phycocyanin operon, and two genes of the microcystin synthetase gene cluster to show that all 12 food supplement samples, sourced from various internet distributors and containing non-toxic A. flos-aquae, also contained toxigenic cyanobacteria. Sequencing of the microcystin synthetase genes detected in all of the food supplements showed that M. aeruginosa was the organism responsible for the production of microcystins in the samples. The presence of microcystins in the food supplements was confirmed by ELISA, with concentrations within the range of $0.1-4.72 \mu \mathrm{g} \mathrm{g}^{-1}$ (microcystin-LR equivalents). Given that the molecular methods applied here are highly sensitive, and show good agreement with the results obtained from ELISA, we believe that they could potentially be used as a quality control technique for food products that contain cyanobacteria.
\end{abstract}

Keywords: Aphanizomenon; Microcystin; Microcystis; Health food supplements

\section{Introduction}

The presence of cyanobacteria in freshwaters is of increasing concern worldwide due to the ability of many

\footnotetext{
* Corresponding author. Tel.: +351 2234 01813; fax: +351 223390608.

E-mail address: martinsaker@hotmail.com (M.L. Saker).
}

species to produce toxins that are harmful to humans and other animals. Of over 1500 known species of cyanobacteria, less than 30 have been found to produce toxic compounds. Among the potentially toxic species, several chemically and toxicologically diverse compounds have been isolated, purified and characterized (Sivonen and Jones, 1999).

Microcystis aeruginosa is one of the most common freshwater bloom-forming species of cyanobacteria. This 
organism produces a group of compounds known as cyclic peptides (also known as microcystins), which have molecular weights ranging from 800 to 1100 . Other genera of cyanobacteria including Anabaena and Planktothrix are also known to produce these compounds. To date, more than 60 microcystin variants have been chemically identified, with the major differences between variants related to either the substitution, epimerization or the demethylation of amino acids (Burns et al., 2004). These compounds have $\mathrm{LD}_{50}$ values (mouse i.p.) in the range of 50-500 $\mathrm{mg} \mathrm{kg}^{-1}$. M. aeruginosa has been implicated in the death of wild and domestic animals (Ressom et al., 1994) and the death of humans (Jochimsen et al., 1998; KuiperGoodman et al., 1999). Furthermore, these toxins have been shown to be tumor promoters in mice and have been linked to liver cancer in humans (Nishiwaki-Matsushima et al., 1992). In recognition of their toxicity, the World Health Organization has implemented a maximum allowable concentration of microcystin in drinking water of $1 \mu \mathrm{g} \mathrm{L}^{-1}$ (WHO, 1998).

Although exposure to microcystins through drinking water and recreational activities is widely recognized, there have been few studies investigating the potential for exposure to these toxins through the consumption of contaminated food. One possible route involves the consumption of food supplements containing cyanobacteria. In the past two decades, there has been increasing interest in the potential health benefits that can be gained by the consumption of Aphanizomenon flos-aquae (Ralfs ex Born. \& Flah). Although some strains of this species have been reported to produce PSP (Ferreira et al., 2001; Pereira et al., 2000) toxins and anatoxin-a (Rapala et al., 1993), more recent studies have shown that in many cases, toxin-producing Aphanizomenon species are misidentified as toxic strains of $A$. flos-aquae when they in fact belong to another closely related species, A. issatschenkoi (Li et al., 2003). Among the reported health benefits of consuming A. flos-aquae are; weight loss, increased energy, mental clarity, 'HIV-improvement', elevated mood and general 'detoxification' (http://www.bluegreenfoods.com/). Whilst many of these claims are unfounded based on scientific evidence, studies have shown that A. flos-aquae produces compounds with anti-bacterial (Østensvik et al., 1998) and anti-mutagenic properties (Lahitova et al., 1994) and is a rich source of polyunsaturated fatty acids (Kushak et al., 2000). Most of the A. flos-aquae that is available commercially is harvested from Lake Klamath, Oregon, USA, where this cyanobacterium grows to high cell densities under natural conditions. In contrast to other cyanobacteria that are used for human consumption such as Spirulina (which is usually grown in artificial ponds), A. flos-aquae is collected directly from the natural environment. The potential therefore exists for the inclusion of other organisms, including toxin-producing cyanobacteria, in the health food supplements. The process of harvesting and incorporation of A. flos-aquae into tablets and capsules for distribution to consumers has been described in detail by Carmichael et al. (2000).
In 1996, a bloom of $M$. aeruginosa in Lake Klamath alerted health care workers to the contamination of A. flos-aquae-containing with a toxin-producing cyanobacterium. A subsequent survey of commercially available food supplements containing A. flos-aquae showed that of 87 samples collected from various sources, 85 contained microcystins at concentrations up to $16.4 \mu \mathrm{g} \mathrm{g}^{-1}$ (Gilroy et al., 2000). Sixty-three of the 87 samples (72\%) contained concentrations greater than $1 \mu \mathrm{g} \mathrm{g}^{-1}$. As a result of that study, and based on the results of a risk assessment analysis, the Oregon State Health Department has enforced a maximum allowable concentration of microcystin-LR in health food supplements of $1 \mu \mathrm{g} \mathrm{g}^{-1}$. Another study, conducted by Health Canada, further highlighted the prevalence of microcystins in A. flos-aquae-containing products distributed throughout Canada and North America (Lawrence et al., 2001).

In these studies, toxins were characterized using ELISA and HPLC techniques. Whilst these analyses are useful for identifying potentially dangerous concentrations of cyanobacterial toxins such as microcystins, they provide no information regarding the source of the contaminant. In this study we applied molecular techniques in an attempt to identify the contaminating organisms present in health food supplements. DNA was extracted from the health food supplements, and polymerase chain reaction (PCR) was then used to amplify two micrcystin synthetase genes. One of the primer sets used in this study was designed to target the aminotransferase gene of microcystin and nodularin synthetases from all hepatotoxic cyanobacteria (Jungblut and Neilan, unpublished). The second set was based on a sequence of the $m c y A$ module of microcystin synthetase from $M$. aeruginosa PCC7806. Sequences obtained from the purified PCR reaction products were then used to identify the contaminating organism, by comparison with other published sequences, using the BLAST search on GenBank. The concentration of microcystins in the food supplements was then measured using ELISA. The molecular techniques described here were found to be useful for the identification of contaminating organisms present in the food supplements. Similar techniques have been used for the identification of toxin-producing cyanobacteria strains in mixed-species phytoplankton samples (Pan et al., 2002; Kurmayer et al., 2003; Burns et al., 2004), and have been used to provide an 'early warning system' for cyanobacterial bloom populations in drinking water supplies (Baker et al., 2001). This study is the first report of their application to food products used for human consumption.

\section{Methods}

\subsection{Source of sample}

Samples of A. flos-aquae-containing food supplements were obtained from several sources. Samples 1-7 (Table 1) 
Table 1

Concentrations of microcystins detected in food supplements sold for human dietary use

\begin{tabular}{lllll}
\hline No. & Sample & $\begin{array}{l}\text { ELISA } \\
\text { present } \\
\text { study) } \\
\mu \mathrm{g} \mathrm{g}^{-1}\end{array}$ & $\begin{array}{l}\text { Microcystins } \\
\text { HPLCa, } \mu \mathrm{g} \mathrm{g}^{-1}\end{array}$ & $\begin{array}{l}\text { ELISA, } \\
\mu \mathrm{g} \mathrm{g}^{-1 \mathrm{a}}\end{array}$ \\
\hline 1 & OR-01a & 1.03 & LR + LA (1.4) & $2.1-2.2$ \\
2 & OR-04a & 1.03 & LR +LA (1.9) & 2.9 \\
3 & OR-06a & 0.10 & LR + LA (5.6) & 0.4 \\
4 & OR-14a & 0.76 & LR + LA (1.4) & 2.2 \\
5 & OR-22a & 4.73 & LR +LA (5.7) & $5.8-6.2$ \\
6 & OR-28a & 0.46 & LR + LA (1.8) & 2.3 \\
7 & WR-21a & 3.49 & LR + LA (2.8-4.2) & 6.1 \\
8 & KB-01 & 0.02 & - & - \\
9 & DT-01 & 0.22 & - & - \\
10 & SN-01 & 0.10 & - & - \\
11 & SN-02 & 0.38 & - & - \\
12 & KS-01 & 0.14 & - & - \\
\hline
\end{tabular}

${ }^{a}$ Data from Lawrence et al. (2001).

were originally included in a survey of microcystin contamination of health food products throughout the USA and Canada, carried out by the Food Research Division of Health Canada (Lawrence et al., 2001). Since their collection, samples were maintained at low temperatures $\left(-20^{\circ} \mathrm{C}\right)$. Samples $8-12$ were obtained from internet distributors in the USA and Europe during May 2004. All A. flos-aquae-containing health food supplements that are available commercially are harvested, processed and distributed by a small number of companies that operate at Upper Klamath Lake, Klamath Falls, Oregon, USA. This lake is characterized by seasonal blooms of A. flos-aquae, which dominate the phytoplankton from June to October. Other cyanobacteria including Anabaena flos-aquae, Coelosphaerium, Microcystis aeruginosa as well as species belonging to the Order Oscillatoriales are also known to occur (Carmichael et al., 2000).

\subsection{DNA extraction}

The samples of A. flos-aquae, obtained from various sources in the form of powders, capsules and tablets, were homogenized with a mortar and pestle. Approximately, $10 \mathrm{mg}$ of each sample was used for extraction of DNA. Samples were combined with $500 \mu \mathrm{l}$ of XS buffer (1\% potassium-methylxanthogenate; $800 \mathrm{mM}$ ammonium acetate; $20 \mathrm{mM}$ EDTA; $1 \%$ SDS; $100 \mathrm{mM}$ Tris-HCl, pH 7.4) and incubated at $65^{\circ} \mathrm{C}$ for $2 \mathrm{~h}$ (vortexed after $1 \mathrm{~h}$ ). The solutions were then placed on ice for $10 \mathrm{~min}$, and centrifuged at $12,000 \mathrm{~g}$ for $10 \mathrm{~min}$. The supernatant was collected and the DNA precipitated by adding 1 volume of isopropanol and 1/10 volume of $4 \mathrm{M} \mathrm{KOAc}$ for $15 \mathrm{~min}$ at $4{ }^{\circ} \mathrm{C}$ followed by a centrifugation step at $12,000 \mathrm{~g}$ for $20 \mathrm{~min}$. DNA was washed with $70 \%$ ethanol, centrifuged at $12,000 \mathrm{~g}$ for $15 \mathrm{~min}$, dried, and resuspended in $50 \mu \mathrm{l}$ of milli$\mathrm{Q}$ water.

\subsection{Polymerase chain reaction $(P C R)$}

16S rDNA amplification was performed in $20 \mu \mathrm{l}$ reactions using primers $27 \mathrm{~F}$ and $809 \mathrm{R}$ (Table 2), with an initial denaturation step at $92^{\circ} \mathrm{C}$ for 2 min followed by 35 cycles of $94{ }^{\circ} \mathrm{C}$ for $10 \mathrm{~s}, 60^{\circ} \mathrm{C}$ for $20 \mathrm{~s}$ and $72{ }^{\circ} \mathrm{C}$ for $1 \mathrm{~min}$ and a final extension step at $72{ }^{\circ} \mathrm{C}$ for 5 min (Jungblut et al., 2005).

The phycocyanin gene was amplified using $\mathrm{PC} \beta \mathrm{F}$ and PC $\alpha$ R primers (Table 2) with 35 cycles of $92^{\circ} \mathrm{C}$ for $20 \mathrm{~s}$, $52^{\circ} \mathrm{C}$ for $30 \mathrm{~s}$ and $72{ }^{\circ} \mathrm{C}$ for $1 \mathrm{~min}$ (Neilan et al., 1995).

Hepatotoxin (Hep)-PCR reactions were performed using primers HepF and HepR (Table 2). The initial denaturation step at $92{ }^{\circ} \mathrm{C}$ for $2 \mathrm{~min}$ was followed by 35 cycles of denaturation at $92{ }^{\circ} \mathrm{C}$ for $20 \mathrm{~s}$, annealing at $52{ }^{\circ} \mathrm{C}$ for $30 \mathrm{~s}$, extension at $72{ }^{\circ} \mathrm{C}$ for $1 \mathrm{~min}$ and a final extension step at $72^{\circ} \mathrm{C}$ for $5 \mathrm{~min}$ (Jungblut and Neilan, unpublished). All Hep-PCR reactions were performed using 0.2 units of Taq polymerase (Fischer Biotech, Perth, Australia) in a $20 \mu 1$ reaction volume containing $2.5 \mathrm{mM} \mathrm{MgCl}_{2}, 1 \mathrm{x}$ Taq-

Table 2

Oligonucleotide primers used in this study for the amplification of cyanobacterial $16 \mathrm{~S}$ rDNA (27F, 809R), phycocyanin operon (PC $\beta F / P C \alpha R$ ) and cyanobacterial hepatotoxin synthetase genes $(\mathrm{QmetF} / \mathrm{R}, \mathrm{HepF} / \mathrm{R})$

\begin{tabular}{|c|c|c|c|c|}
\hline Designation & Target gene & Sequence & $\begin{array}{l}\text { Annealing } \\
\text { temp. }\left({ }^{\circ} \mathrm{C}\right)\end{array}$ & Reference \\
\hline $\begin{array}{l}27 \mathrm{~F} \\
809 \mathrm{R}\end{array}$ & 16S rDNA & $\begin{array}{l}\text { 5'-AGAGTTTGATCCTGGCTCAG-3', } \\
\text { 5'-GCTTCGGCACGGCTCGGGTCGATA-3' }^{\prime}\end{array}$ & 52 & $\begin{array}{l}\text { Salmon and Neilan } \\
\text { (unpublished) }\end{array}$ \\
\hline $\begin{array}{l}\mathrm{PC} \beta \mathrm{F} \\
\mathrm{PC} \alpha \mathrm{R}\end{array}$ & Phycocyanin & $\begin{array}{l}\text { 5'-GGCTGCTTGTTTACGCGACA-3', } \\
5^{\prime} \text {-CCAGTACCACCAGCAACTAA-3' }\end{array}$ & 50 & Neilan et al. (1995) \\
\hline $\begin{array}{l}\text { QmetF, } \\
\text { QmetR }\end{array}$ & $m c y \mathrm{~A}$ & $\begin{array}{l}\text { 5'-TTATTCCAAGTTGCTCCCCA-3', } \\
5^{\prime} \text {-GGAAATACTGCACAACCGAG-3' }\end{array}$ & 55 & $\begin{array}{l}\text { Gehringer and Neilan } \\
\text { (unpublished) }\end{array}$ \\
\hline $\begin{array}{l}\text { HepF, } \\
\text { HepR }\end{array}$ & $\begin{array}{l}\mathrm{AMT}^{\mathrm{a}} \\
m c y \mathrm{E}\end{array}$ & $\begin{array}{l}5^{\prime} \text { TTTGGGGTTAACTTTTTTGGCCATAGTC '3, } \\
5^{\prime} \text { AATTCTTGAGGCTGTAAATCGGGTTT ' } 3\end{array}$ & 52 & $\begin{array}{l}\text { Jungblut and Neilan } \\
\text { (unpublished) }\end{array}$ \\
\hline
\end{tabular}

a Aminotransferase. 
Polymerase buffer (Fischer Biotech), $0.2 \mathrm{mM}$ of dNTPs (Fischer Biotech, Perth, Australia) and $0.5 \mathrm{pM}$ of forward and reverse primers.

The Qmet-PCR reactions were performed as described for the $16 \mathrm{~S}$ rDNA amplification. The protocol was carried out with an initial $2 \mathrm{~min}$ denaturation step at $95^{\circ} \mathrm{C}$ followed by 30 cycles of $95{ }^{\circ} \mathrm{C}$ for $20 \mathrm{~s}, 55^{\circ} \mathrm{C}$ for $30 \mathrm{~s}$ and $72{ }^{\circ} \mathrm{C}$ for $50 \mathrm{~s}$. This was followed by a final annealing step at $72{ }^{\circ} \mathrm{C}$ for 7 min. For all PCR reactions ca. $1 \mathrm{ng}$ of chromosomal DNA was used. All PCR products were analyzed on $2 \%$ agarose gels with $1 \times$ TAE buffer and stained with ethidium bromide $\left(1 \mu \mathrm{g} \mathrm{ml}^{-1}\right)$ for $10 \mathrm{~min}$. A Gel-DOC Bio-RAD System with Quantity One 4.1R software (BIO-RAD, USA) was used for photographic documentation.

\subsection{Sequencing and sequence analysis}

Sequencing of the PCR products was carried out using primers HepF, 809R, QmetR and PC $\beta F$. Automated sequencing was performed using the PRISM Big Dye cycle sequencing system and ABI 3730 Capillary Applied Biosystem (Foster City, CA). Sequence data was analyzed using the Applied Biosystem Auto-Assembler computer program. The identities of the sequenced amplicons were determined using a BLAST search on GenBank. All sequences were checked manually for quality of the data.

\subsection{Analysis of microcystins using ELISA}

The presence of microcystins in health foods obtained from various sources (Table 1) was determined using the Envirogard ${ }^{\circledR}$ Microcystin Plate Kit (Strategic Diagnostic, Inc., Newark, USA). This assay uses antibodies against microcystin-LR, the most common microcystin (Chu et al., 1990). Briefly, $20 \mathrm{mg}$ of material was extracted in $5 \mathrm{ml}$ of milli-Q ultrapure water with sonication on ice. The solution was then centrifuged at $10,000 \mathrm{~g}$ for $5 \mathrm{~min}$ and the supernatant filtered $(0.2 \mu \mathrm{m})$ and applied to the assay kit. The absorbance was measured using a Well-Scan ELISA plate reader (Denley Corp., UK) at a wavelength of $450 \mathrm{~nm}$.

\section{Results}

The cyanobacterial specific $16 \mathrm{~S}$ rDNA PCR resulted in a product for all of the samples, indicating that all of the food supplements investigated in this study contained cyanobacterial DNA (Fig. 1). The $16 \mathrm{~S}$ rDNA PCR products were purified and sequenced. A 782-bp partial sequence was generated between positions 27 and 809 for all of the samples, corresponding to the $E$. coli $16 \mathrm{~S}$ rDNA sequence numbering. The assembled sequences were analyzed using the BLAST program in GenBank (Altschul et al., 1990) for alignment to database sequences and to confirm that the origin of the generated sequence was cyanobacterial.

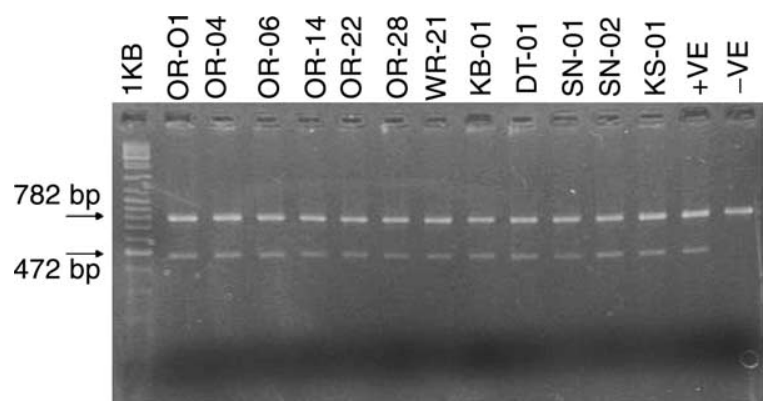

Fig. 1. The cyanobacterial specific $16 \mathrm{~S}$ rDNA PCR amplified a 782-bp fragment from all of the health supplement samples analyzed. The Hep primer set amplified a ca. 472-bp product from all food supplements containing cyclic peptide of toxigenic cyanobacteria. Microcystis aeruginosa PCC7806 was used as the positive control and a non-toxic Anabaena strain (NIES 19) was used as a negative control. A $1 \mathrm{~KB}$ molecular ladder is also shown.

The 16S rDNA gene sequences were then compared to each other and to other sequences available in GenBank.

The 16S rDNA sequences obtained from the food supplements showed more than $97 \%$ similarity to Aphanizomenon sp. (Table 3). All samples except OR-14 showed the same high level of similarity to sequences of A. flos-aquae PMC9707 (accession no: AFL293130), A. gracile PMC9402 (AGR2931270), A. flos-aquae PMC9401 (AFL293126), A. flos-aquae var. Klebahnii 218 (AFL293123), A flos-aquae var. Klebahnii 83 (AFL293122) and Aphanizomenon sp. 326 (AFL293121). In addition, samples OR-28, DT-01 and SN-01 showed high sequence similarity to A. flos-aquae str. 'Aph Zayi' (AY196082.1) and A. flos-aquae str. 'Aph Ku' (AY196085.1). Sample OR-14 also displayed a high level of similarity to Aphanizomenon sp., although the highest similarity was detected with A. flos-aquae str. 'Aph Inba' (AY196083.1). Despite the strong similarity between the samples in terms of their 16S rDNA sequences, a manual check showed that all of the sequences were contaminated with other $16 \mathrm{~s}$ rDNA PCR products.

To further characterize the species present in the cyanobacterial-containing food supplements, the phycocyanin operon was amplified and sequenced, using the primers shown in Table 2. The products obtained from this PCR reaction were analyzed on a $2 \%$ gel, then purified and sequenced and found to consist of a 650-bp fragment from the phycocyanin operon. Analysis of the sequence data using GenBank showed highest similarity (94\%) to the phycocyanin operon of Aphanizomenon sp. and Anabaena sp. As was the case with the cyanobacterial specific $16 \mathrm{~S}$ DNA sequences, all of the phycocyanin gene sequences were found to be contaminated with another phycocyanin gene product.

The Hep PCR reactions resulted in amplification of a 472-bp fragment for all twelve samples analyzed in this study. The PCR-products were sequenced in order to 
Table 3

Highest similarities of the sequence analysis in GenBank by BLASTN or BLASTX of the investigated food supplements using cyanobacterial specific 16S rDNA primers, Hep- and Qmet primers. NT, not tested

\begin{tabular}{|c|c|c|c|c|c|c|}
\hline Sample & $\%$ & 16S rDNA Highest match NCBI & $\%$ & Hep highest match NCBI & $\%$ & $\begin{array}{l}\text { Qmet highest } \\
\text { match NCBI }\end{array}$ \\
\hline OR-01 & 98 & $\begin{array}{l}\text { A. flos-aquae PMC9707 } \\
\text { (AFL293130), A. gracile PMC9402 } \\
\text { (AGR2931270), } \\
\text { A. flos-aquae PMC9401 } \\
\text { (AFL293126), A flos-aquae var. } \\
\text { Klebahnii } 218 \text { (AFL293123), } \\
\text { A flos-aquae var. Klebahnii } 83 \\
\text { (AFL293122), A sp. } 326 \\
\text { (AFL293121) }\end{array}$ & 96 & $\begin{array}{l}\text { McyE, M. aeruginosa } \text { PCC7806 } \\
\text { (AAF00958.1), McyE, } \\
\text { M. aeruginosa } \text { K-139 (BAB12211.1) }\end{array}$ & & NT \\
\hline OR-04 & 97 & See sample OR-01 & 97 & $\begin{array}{l}\text { McyE, M. aeruginosa } \text { PCC7806 } \\
\text { (AAF00958.1), McyE, } \\
\text { M. aeruginosa } \text { K-139 (BAB12211.1) }\end{array}$ & & NT \\
\hline OR-06 & 98 & See sample OR-01 & 96 & $\begin{array}{l}\text { McyE, } \text { M. aeruginosa } \text { PCC7806 } \\
\text { (AAF00958.1), McyE, } \\
\text { M. aeruginosa } \text { K-139 (BAB12211.1) }\end{array}$ & & NT \\
\hline OR-14 & 98 & $\begin{array}{l}\text { A. flos-aquae str. 'Aph Inba' } \\
\text { (AY196083.1) }\end{array}$ & 97 & $\begin{array}{l}\text { McyE, } \text { M. aeruginosa } \text { PCC7806 } \\
\text { (AAF00958.1), McyE, } \\
\text { M. aeruginosa } \text { K-139 (BAB12211.1) }\end{array}$ & & NT \\
\hline OR-22 & 97 & See sample OR-01 & 96 & $\begin{array}{l}\text { McyE, M. aeruginosa } \text { PCC7806 } \\
\text { (AAF00958.1), McyE, } \\
\text { M. aeruginosa } \text { K-139 (BAB12211.1) }\end{array}$ & 100 & $\begin{array}{l}\text { McyA } \\
\text { M. aeruginosa } \\
\text { PCC7806 } \\
\text { (AAF17323.1) }\end{array}$ \\
\hline OR-28 & 98 & $\begin{array}{l}\text { A. flos-aquae PMC9707 } \\
\text { (AFL293130), A. gracile PMC9402 } \\
\text { (AGR2931270), } \\
\text { A. flos-aquae PMC9401 } \\
\text { (AFL293126), A flos-aquae var. } \\
\text { Klebahnii } 218 \text { (AFL293123), } \\
\text { A flos-aquae var. Klebahnii } 83 \\
\text { (AFL293122), A sp. } 326 \\
\text { (AFL293121), A. flos-aquae str. } \\
\text { 'Aph Zayi' (AY196082.1), } \\
\text { A. flos-aquae str. 'Aph Ku' } \\
\text { (AY196085.1) }\end{array}$ & 97 & $\begin{array}{l}\text { McyE, M. aeruginosa } \text { PCC7806 } \\
\text { (AAF00958.1), McyE, } \\
\text { M. aeruginosa K-139 (BAB12211.1) }\end{array}$ & & NT \\
\hline WR-21 & 98 & See sample OR- 01 & 97 & $\begin{array}{l}\text { McyE, M. aeruginosa } \text { PCC7806 } \\
\text { (AAF00958.1), McyE, } \\
\text { M. aeruginosa } \text { K-139 (BAB12211.1) }\end{array}$ & 100 & $\begin{array}{l}\text { McyA } \\
\text { M. aeruginosa } \\
\text { PCC7806 } \\
\text { (AAF17323.1) }\end{array}$ \\
\hline KB-01 & 98 & See sample OR-01 & 97 & $\begin{array}{l}\text { McyE, } \text { M. aeruginosa } \text { PCC7806 } \\
\text { (AAF00958.1), McyE, } \\
\text { M. aeruginosa } \text { K-139 (BAB12211.1) }\end{array}$ & & NT \\
\hline DT-01 & 97 & See sample OR-28 & 92 & $\begin{array}{l}\text { McyE, M. aeruginosa } \mathrm{K}-139 \\
\text { (BAB12211.1) }\end{array}$ & & NT \\
\hline SN-01 & 96 & See sample OR-28 & 97 & $\begin{array}{l}\text { McyE, } \text { M. aeruginosa } \text { PCC7806 } \\
\text { (AAF00958.1), McyE, } \\
\text { M. aeruginosa } \text { K-139 (BAB12211.1) }\end{array}$ & 97 & $\begin{array}{l}\text { McyA } \\
\text { M. aeruginosa } \\
\text { PCC7806 } \\
\text { (AAF17323.1) }\end{array}$ \\
\hline $\mathrm{SN}-02$ & 98 & See sample OR-01 & 96 & $\begin{array}{l}\text { McyE, } \text { M. aeruginosa } \text { PCC7806 } \\
\text { (AAF00958.1), McyE, } \\
\text { M. aeruginosa } \text { K-139 (BAB12211.1) }\end{array}$ & & NT \\
\hline KS-01 & 97 & See sample1 OR-01 & 97 & $\begin{array}{l}\text { McyE, M. aeruginosa } \text { PCC7806 } \\
\text { (AAF00958.1), McyE, } \\
\text { M. aeruginosa } \text { K-139 (BAB12211.1) }\end{array}$ & 100 & $\begin{array}{l}\text { McyA } \\
\text { M. aeruginosa } \\
\text { PCC7806 } \\
\text { (AAF17323.1) }\end{array}$ \\
\hline
\end{tabular}


confirm the identity of the amplified fragments. Sequence analysis of the amplicons showed that all conformed to the expected gene fragment of the aminotransferase (AMT) found in $m c y \mathrm{E}$ from the cyanobacterial multi-enzyme complex of microcystin synthetase. The DNA sequences were then compared with other published sequence data on GenBank and found to show highest similarity (at least 97\%) to $m c y \mathrm{E}$ of the microcystin synthetase gene from M. aeruginosa PCC7806 (AAF00958.1) and mcyE from $M$. aeruginosa K-139 (BAB12211.1) (Table 3). The samples were clearly different to the published sequences of the microcystin synthetase gene of other hepatotoxic species such as Planktothrix sp. CYA 126/8 and Anabaena sp. strain 90. Both of these strains yielded similarities of less than $88 \%$. As an additional confirmation, PCR was carried out on all samples using the Qmet primer set (Table 2). These primers were designed to target the mcyA module of the microcystin synthetase of $M$. aeruginosa. For all samples, a 200-bp PCR-product was amplified and representative PCRamplicons from samples OR-22, WR-21, SN-01 and KS-01 were sequenced in order to confirm the source of the product. In all cases, the PCR products showed greatest similarity (97 to $100 \%$ in the GenBank BLASTX search) to the mcyA region of the non-ribosomal peptide synthetase of microcystin synthetase from $M$. aeruginosa PCC7806 (AAF17323.1; Table 3).

The presence of microcystins in all of the food supplements was confirmed by ELISA (Table 1), however, there was considerable variation in the concentrations detected within the samples, which ranged from 0.10 to $4.72 \mu \mathrm{g} \mathrm{g}^{-1}$. In general, the microcystin content of the samples included in the Lawrence et al. (2001) study yielded higher concentrations than those that were purchased from internet distributors in May 2004 (Table 1). Furthermore, the samples that were included in the Lawrence et al. (2001) study and re-analyzed in this study yielded microcystin concentrations that were $50-75 \%$ lower than the values that were originally reported.

\section{Discussion}

The presence of hepatotoxic compounds such as microcystins, in products marketed for their health properties is a cause for concern. While other reports have highlighted the presence of microcystins in these supplements (Lawrence et al., 2001; Gilroy et al., 2000), this is the first report showing the identity of the contaminating organism. In this study we were unable to identify the contaminating species using conventional techniques such as microscopy, or characterization of the $16 \mathrm{~S}$ rDNA or phycocyanin operon, due to the presence of more than one species or DNA type in the DNA extracts which were used as the template for PCR. However, analysis of the PCR products obtained using primers that were specifically designed to target the genes responsible for microcystin production suggested a clear origin of the toxigenic contaminants. The nucleotide sequences obtained for the Hep-PCR products all twelve samples showed a very high similarity $(>96 \%)$ to fragments of the microcystin synthetase gene reported for Microcystis species. Much lower similarities $(<88 \%)$ were obtained when the sequences were compared with the microcystin synthetases genes reported for other toxigenic genera including Planktothrix and Anabaena. This result indicates that Microcystis sp. was the source of contamination in all of the food supplement samples. This result was confirmed by sequencing of the PCR-products obtained using the Qmet primers, which provided nucleotide sequence similarity in the range of $97-100 \%$.

The ability to identify toxigenic species such as $M$. aeruginosa, based on sequence analysis of the microcystin synthetase genes has been discussed in other studies and suggests the congruent evolution of cyanobacterial speciation and microcystin synthetases (Rantala et al., 2004; Jungblut and Neilan, unpublished). Such an evolution indicates that the microcystin synthetase genes carried by microcystin producing species demonstrate a close phylogenetic relationship between microcystin producing cyanobacteria. Microcystis is one of the many genera known to produce microcystins and it is likely that the techniques used in this study are equally as useful for detecting the presence of other known microcystinproducing genera including Anabaena, Planktothrix, Nostoc, Hapalosiphon and Anabaenopsis. Studies of the phytoplankton at Klamath Lake have shown that several other genera of toxin producing cyanobacteria are present in this water body. However, whilst the contaminated sequences obtained for the 16s rDNA and phycocyanin operon indicated the presence of more than one type of cyanobacterial DNA, there was no evidence of contamination of either the Hep or Qmet sequecnces. This result indicates that among the samples tested in this study, $M$. aeruginosa was the only cyanobacterium potentially capable of producing cyclic peptides. The possible presence of other cyanotoxins cannot be discounted without further detailed analyses. To date, it remains unclear whether strains of Aphanizomenon flos-aquae are capable of producing compounds that can effect human health (Li et al., 2003) however, there are no published reports of microcystin production by strains of A. flosaquae and it should also be noted that neurotoxins have never been detected in the phytoplankton from Klamath Lake. Another species belonging to the Genus Aphanizomenon, A. ovalisporum has been shown to produce a potent hepatotoxin known as cylindrospermopsin (Banker et al., 1997).

Based on previous studies investigating the potential health related effects of microcystins in food supplements (Gilroy et al., 2000), a value of $1 \mu \mathrm{g} \mathrm{g}^{-1}$ was considered to be an appropriate safety level for food products used for human consumption. It has also been reported that this level 
is highly conservative and that based on the results of a mouse assay, could justifiably be increased to $10 \mu \mathrm{g} \mathrm{g}^{-1}$ (Schaeffer et al., 1999). The results of this study have confirmed that despite the high concentrations obtained for some of the samples collected in the period from 2000 to 2001 (up to $4.72 \mu \mathrm{g} \mathrm{g}^{-1}$ ), the samples collected in May 2004 were within an acceptable range from 0.02 to $0.38 \mu \mathrm{g} \mathrm{g}^{-1}$, and demonstrate the vigilance of the health food companies for controlling the concentrations within their products.

The re-analysis of samples collected in the study conducted by Health Canada (Lawrence et al., 2001) resulted in concentrations much lower than those originally reported (Table 1). This might have been caused by the different methodologies used in the two studies. It is well known that different ELISA techniques can potentially provide different results (Metcalf et al., 2000; Metcalf and Codd, 2003). While the earlier study used the Envirologix kit, here we employed the Envirogard kit. It is also possible that microcystins may have been degraded in the samples over the 4-year period since their original collection. While some of the products, according to the label, consisted of $100 \%$ freeze-dried cyanobacteria others were diluted with various binding agents and preservatives such as gelatin, modified cellulose gum, magnesium stearate, stearic acid, silicon dioxide, fluctooligosaccaride, soy lecithin, sesame meal and Acacia. Some were also supplemented with vitamins such as Vitamin C and niacin. While the addition of these compounds may have affected the concentration of microcystins (expressed on a gravimetric basis), they did not appear to influence the efficacy of DNA extraction or inhibit the various PCR reactions employed in this study.

The techniques used in this study were found to be highly sensitive for detecting the presence of microcystinproducing contaminating microorganisms in health food products. Increasing interest in the use of molecular techniques have lead to the identification of the genes responsible for the production of some other cyanobacterial toxins such as cylindrospermopsin (Schembri et al., 2001) and nodularin (Moffit and Neilan, 2001). If used in combination with other chemical and biochemical techniques such as HPLC, ELISA and the protein phosphatase assay, the molecular techniques could be useful for the rapid, sensitive and routine monitoring and quality control of products containing cyanobacteria that are used for human consumption.

\section{Acknowledgements}

This study was funded by a post-doctoral scholarship to M.L. Saker provided by the Fundação para a Ciência e a Tecnologia (SFRH/BPD/8059/2002).

\section{References}

Altschul, S.F., Gish, W., Miller, W., Myers, E.W., Lipman, D.J., 1990. Basic local alignment search tool. Journal of Molecular Biology 215, 403-410.

Baker, J.A., Neilan, B.A., Entsch, B., McKay, D.B., 2001. Identification of cyanobacteria and their toxigenicity in environmental samples by rapid molecular analysis. Environmental Toxicology 16, 472-482.

Banker, R., Carmeli, S., Hadas, O., Teltsch, B., Porat, R., Sukenik, A., 1997. Identification of cylindrospermopsin in the cyanobacterium Aphanizomenon ovalisporum (Cyanophyceae) isolated from Lake Kinneret, Israel. Journal of Phycology 33, 613616.

Burns, B.P., Saker, M.L., Moffitt, M., Neilan, B.A., 2004. Molecular detection of the genes responsible for cyanobacterial toxin production in the genera Microcystis, Nodularia and Cylindrospermopsis. In: Spencer, J.F.T, Ragout de Spencer, A.L. (Eds.), Methods in Molecular Biology Public Health Microbiology: Methods and Protocols, vol. 268. Humana Press, Totowa, NJ, USA.

Carmichael, W.W., Drapeau, C., Anderson, D.M., 2000. Harvesting of Aphanizomenon flos-aquae ralfs ex Born and flah. Var. flosaquae (Cyanobacteria) from Klamath Lake for human dietary use. Journal of Applied Phycology 12, 585-595.

Chu, F.S., Huang, X., Wei, R.D., 1990. Enzyme linked immunosorbent assay for microcystin in blue green algal blooms. Journal of the Association of Official Analytical Chemists 73, 451-456.

Ferreira, F.M.B., Soler, J.M.F., Fidalgo, M.L., Fernández, P., 2001. PSP toxins from Aphanizomenon flos-aquae (cyanobacteria) collected in the crestuma-lever reservoir (Douro River, Northern Portugal). Toxicon 39, 757-761.

Gehringer, M.M., Moffitt, M.C., Pan, Y., White, P.A., Neilan, B.A., unpublished. Quantitative PCR for the detection of microcystin producing cyanobacteria.

Gilroy, D.J., Kauffman, K.W., Hall, R.A., Huang, X., Chu, F.S., 2000. Assessing potential health risks from microcystin toxins in blue-green algae dietary supplements. Environmental Health Perspectives 108 (5), 435-439.

Jochimsen, E.M., Carmichael, W.W., Am, J., Cardo, D.M., Cookson, S.T., Holmes, C.E.M., Antunes, M.B. de C., Filho, D.A. de M., Lyra, T.M., Barreto, V.S.T., Azevedo, S.M.F.O., Jarvis, W.R., 1998. Liver failure and death after exposure to microcystins at a haemodialysis centre in Brazil. New England Journal of Medicine 338 (13), 873-878.

Jungblut, A.-D., Neilan, B.A., unpublished. Molecular evolution and detection of cyclic peptide hepatotoxins in three orders of cyanobacteria.

Jungblut, A.-D., Hawes, I., Mountfort, D., Dietrich, D.R., Burns, B.P., Neilan, B.A., 2005. Diversity within cyanobacterial mat communities in variable salinity meltwater ponds of McMurdo ice shelf, Antarctica. Enivronmental Microbiology 7 (4), 519-529.

Kuiper-Goodman, T., Falconer, I., Fitzgerald, J., 1999. Human health aspects. In: Chorus, I., Bartram, J. (Eds.), Toxic Cyanobacteria in Water. E \& FN Spon, London, England, pp. 113-153.

Kurmayer, R., Christiansen, G., Chorus, I., 2003. The abundance of microcystin-producing genotypes correlates positively with colony size in Microcystis sp. and determines its microcystin net production in Lake Wannsee. Applied and Environmental Microbiology 69 (2), 787-795. 
Kushak, R., Drapeau, C., van Cott, E., Winter, H., 2000. Favourable effects of blue-green algae Aphanizomenon flos-aquae on rat plasma lipids. Journal of the American Nutraceutical Association 2 (3), 59-65.

Lahitova, N., Doupovcova, M., Zvonar, J., Chandoga, J., Hocman, G., 1994. Antimutagenic properties of fresh-water blue-green algae. Folia Microbiologica 39, 301-303.

Lawrence, J.F., Niedzwiadek, B., Menard, C., Lau, B.P.Y., Lewis, D., Kuper-Goodman, T., 2001. Comparison of liquid chromatography/mass spectrometry, ELISA, and phosphatase assay for the determination of microcystins in blue-green algae products. Journal of AOAC International 84 (4), 1035-1044.

Li, R., Carmichael, W.W., Pereira, P., 2003. Morphological and 16S gene evidence for reclassification of the paralytic shellfish toxin producing Aphanizomenon flos-aquae LMECYA 31 as Aphanizomenon issatschenkoi (Cyanophyceae). Journal of Phycology 39, 814-818.

Metcalf, J.S., Codd, G.A., 2003. Analysis of cyanobacterial toxins by immunological methods. Chemical Research in Toxicology 16 (2), 103-112.

Metcalf, J.S., Hyenstrand, P., Beatie, K.A., Codd, G.A., 2000. Effects of physicochemical variables and cyanobacterial extracts on the immunoassay of microcystin-LR by two ELISA kits. Journal of Applied Microbiology 89, 532-538.

Moffit, M.C., Neilan, B.A., 2001. On the presence of peptide synthetase and polyketide synthetase genes in the cyanobacterial genus Nodularia. FEMS Microbiology Letters 196, 207-214.

Neilan, B.A., Jacobs, D., Goodman, A.E., 1995. Genetic diversity and phylogeny of toxic cyanobacteria determined by DNA polymorphisms within the phycocyanin locus. Applied and Environmental Microbiology 61, 3875-3883.

Nishiwaki-Matsushima, R., Ohta, T., Nishiwaki, S., Suganuma, M., Kohyama, K., Ishikawa, T., Carmichael, W.W., Fujiki, H., 1992. Liver tumor promotion by the cyanobacterial cyclic peptide toxin microcystin-LR. Journal of Cancer Research and Clinical Oncology 118, 420-424.

Østensvik, O., Skulberg, O.M., Underal, B., Hormazabal, V., 1998. Antibacterial properties of extracts from selected planktonic freshwater cyanobacteria-a comparative study of bacterial bioassays. Journal of Applied Microbiology 84, 1117-1124.

Pan, H., Song, L., Liu, Y., Börner, T., 2002. Detection of hepatotoxic Microcystis strains by PCR with intact cells from both culture and environmental samples. Archives of Microbiology 178, 421-427.

Pereira, P., Onodera, H., Andrinolo, D., Franca, S., Araujo, F., Lagos, N., Oshima, Y., 2000. Paralytic shellfish toxins in the freshwater cyanobacterium Aphanizomenon flos-aquae, isolated from montargil reservoir, Portugal. Toxicon 38, 1689-1702.

Rantala, A., Fewer, D., Hisburgues, M., Rouhiainen, L., Vaitomaa, J., Börner, T., Sivonen, K., 2004. Phylogenetic evidence for the early evolution of the microcystin synthesis. Proceedings of the National Academy of Sciences 101, 568-573.

Rapala, J., Sivonen, K., Lyra, C., Niemelä, S.I., 1993. Anatoxin-a concentration in Anabaena and Aphanizomenon at different environmental conditions and comparison of growth by toxic and non-toxic Anabaena strains-a laboratory study. Applied and Environmental Microbiology 64, 2206-2212.

Ressom, R., Soong, F.S., Fitzgerald, J., Turczynowicz, L., Saadi, O.E., Roder, D., Maynard, T., Falconer, I.R., 1994. Health Effects of Toxic Cyanobacteria. NHMRC, Australian Government Publishing, Australia p. 108.

Salmon, T.P., Neilan, B.A., unpublished. Amplification of cyanobacterial small subunit-rRNA from natural assemblages.

Schaeffer, D.J., Malpas, P.B., Barton, L.L., 1999. Risk assessment of microcystin in dietary Aphanizomenon flos-aquae. Ecotoxicology and Environmental Safety 44, 73-80.

Schembri, M.A., Neilan, B.A., Saint, C.P., 2001. Identification of genes implicated in toxin production in the cyanobacterium Cylindrospermopsis raciborskii. Environmental Toxicology 16, 413-421.

Sivonen, K., Jones, G., 1999. Cyanobacterial toxins. In: Chorus, I., Bartram, J. (Eds.), Toxic Cyanobacteria in Water. E \& FN Spon, London, England, pp. 41-111.

WHO, 1998.Anon., 1998. Guidelines for drinking-water quality, Addendum to Volume 2, Health Criteria and Other Supporting Information, second ed. World Health Organization, Geneva. 